Brandeis $\left.\right|_{\text {urear }}$

brandeis.edu/j-caste
CASTE: A Global Journal on Social Exclusion

Vol. 1, No. 1, pp. i-vii

February 2020

ISSN 2639-4928

DOI:10.26812/caste.v1i1.159

\title{
Why a Journal on Caste?
}

\section{Part I.An Introduction to the Journal: Laurence Simon}

Our journal is founded on the straightforward principle that social exclusion should not be a consequence of one's birth or ancestry. Caste, in its simplest definition, encompasses all hereditary systems and derived cultures that constrain the fullest human development, acceptance and recognition of equal rights for each and every individual. Yet history is rife with 'natural' hierarchies that have their own, often religious, justifications for quasi-biological groupings based on inherited privilege or stigma. Rawls considers this backdrop to modern theories of justice.

Thus, in a feudal or in a caste system each person is believed to have his allotted station in the natural order of things. His comparisons are presumably confined within his own estate or caste, these ranks becoming in effect so many non-comparing groups established independently of human control and sanctioned by religion and theology. Men resign themselves to their position should it ever occur to them to question it; and since all may view themselves as assigned their vocation, everyone is held to be equally fated and equally noble in the eyes of providence. ${ }^{1}$

In the West, these archaic notions of a fixed and ordained society were derived in part from the Ptolemaic conception of the universe with the earth, man, kings, and aristocracy as the center of God's creation. These were eventually challenged by the emergence of science and rational inquiry. Even in the modern era illusions of superiority were common among early settlers to the Americas. The indigenous peoples of North and South America were eliminated through genocide with their survivors marched through the trail of tears. The English word caste derives from the Latin castus denoting being cut off or separated, and the Portuguese casta carried that further into purity of lineage, race, or breed thus separating the colonial Portuguese from the indigenous and mixed races of Brazil.

This concept of purity can poison cultures and create pseudospeciation, a term first used by the American psychologist Eric Ericson to describe marginalized groups considered so inferior that they have become in the eyes of the oppressor distinct and subpar species. We only have to think of the Europeans' exploitation of the African slave, or blacks in apartheid states of Africa, or the Jews of Imperial Russia who were confined to the Pale of Settlement, limited to Jewish quotas for education and suffering the collective violence of pogroms against their communities. Western history is littered with such dehumanization and their legacies are still palpable in contemporary societies.

'John Rawls, A Theory of Justice (Cambridge, Harvard University Press, 197I) p. 547. 
Asia was the cradle of some of the world's major faiths yet, today in the name of those religions, pogroms are led against religious outsiders in Sri Lanka and Myanmar, and in India. This tragedy of a moral and spiritual corruption has sustained the oldest form of prejudice in the world today: the division of society into rigid, birth-based graded hierarchy of caste. While progress toward social equality has been made, the birth-based caste system has survived millennia and continues to hinder the lives of millions of low-caste and tribal citizens. It remains a leading cause of horrendous acts of violence, including gang rape and lynching, or honor killings for inter-caste romances. It results in suicides on Indian campuses, bias in employment and housing, and a staggering waste of human potential. Despite reformist movements and affirmative action policies, and even after legal protections, the stigma of untouchability still exists in a culture derived from ancient scriptures.

Our journal then intends to encourage and publish scholarship on both the broader experience of caste throughout the world and on the ancient caste system as it still thrives in South Asia. Our articles are carefully peer-reviewed and submitted by scholars from all disciplines in the academy. I heard someone at a conference recently say that scholarship does not matter, that social action does. Yet universities are enormously influential in much of the world and their teachings through curricula expand or constrain the reasoning and reflections of future generations. At heart J-CASTE is a journal about ethics and about moral philosophy. These are the purposeful underpinnings of our perspective. This perspective is deeply rooted at Brandeis, a toptier research university founded on the principle of social inclusion, and which has recently become perhaps the first in the United States to incorporate caste into its nondiscrimination policy.

\section{Part 2. An Introduction to Caste: Sukhadeo Thorat}

This being the first issue of J-CASTE, we think it appropriate to introduce the caste system to readers. It is an ancient organisation of the Hindu that involves the division of the Hindu society into five groups called castes. The origin of caste system goes back to around second century BCE when it was legally codified in Manusmruti. ${ }^{2}$ The system laid down a legal and normative framework to govern all aspects of the society: cultural, economic, religious, spiritual, and political. The moral and legal framework assigned right to property, occupation, education and civil and religious right among the castes. But the assignment and entailment to rights was made in a graded and unequal manner. The caste at the top of hierarchy had most rights and privileges that kept on reducing gradually in descending order of the caste. Further, rights of each of the five castes were fixed in advance and made hereditary by birth. An equally important feature is that each caste is isolated and separated through the rule of endogamy (or marriage within one's caste). Endogamy enforced isolation and social separation of castes from each other and restricted social relations between them. The caste at the bottom of the hierarchy was regarded as 'impure and polluting,' thus 'untouchable' or unfit for any social interaction except among them. Also, they were assigned all the menial tasks of cleaning, scavenging, skinning carcasses, and so on - a stigma associated with them to this day. Traditionally, this caste has had no right

${ }^{2}$ An ancient Hindu scripture in which social laws were codified. 
to property, education, and civic rights, except obligatory services to the four castes above them. Thus, the 'untouchables,' or atishudras in Sanskrit, suffer forced isolation and segregation in virtually all spheres of life. The denial of basic rights, fundamental for the social growth of a human being has had a crippling effect on their psyche from which they have not recovered for many centuries. Thus, caste as a social organisation is governed by the unequal assignment or entitlement of rights, lack of individual freedom, and fraternity: the very antithesis of a fair and just system of governance. This has resulted in deep inter-caste inequalities in all aspects of life.

\section{Constitution, Laws and Policies}

The Indian State at the time of framing Constitution in 1950 recognised the problem arising out of its social organisation of caste system. It made social justice (social, economic and political), liberty, equality, and fraternity the governing principles of the society, overturning the principles on which caste system was founded. The Constitution promises equal rights to all citizens as fundamental rights. Article 14 assures equality before the law and equal protection of law. Article 15 prohibits discrimination on the grounds of caste, religion, race, sex, or place of birth, by the State and in use of services supplied by private individual for public use, and /or facilities maintained wholly or partly out of State funds and dedicated to the use of the general public. Article 16 refers to equality of opportunity in matters of public employment, and states that there shall be equality of opportunity for all citizens in matters relating to employment under the State, and no discrimination in employment or office under the State.

Article 17 abolishes untouchability and its practice in any form is forbidden and made punishable in law. Moreover, the Constitution in Article 46, namely Directive Principles of State Policy, makes it obligatory for the State to enact laws and frame policies to enable the citizens to use these (fundamental) rights in practice thus: 'The State is required to protect the Scheduled Caste (ex-untouchables) and Scheduled Tribes (indigenous people) from social injustices and all forms of exploitation.' In the case of scheduled caste, among other things it means protection in law from caste discrimination and untouchability.

The Indian Government, in 1955, enacted the Untouchability (Offences) Act on May 8, 1955 (enforced on June 1, 1955). It was renamed 'Protection of Civil Rights (PCR) Act, 1979. Thirty-four years later, another law namely 'The Scheduled Castes and Scheduled Tribes (Prevention of Atrocities) Act, was enacted in 1989. The Indian Government also enacted an affirmative action policy to ensure fair share to the scheduled castes/scheduled tribes in legislature, public employment and educational institutions.

Similar constitutional, legal provisions and policies were framed in Nepal after the adoption of its new Constitution. Selective policies to secure protection to social minorities, particularly, the scavenger caste have also been adopted in Pakistan and Bangladesh. In UK, after a report on the caste discrimination faced by the Dalits or the scheduled caste in India, the British Government tabled a bill for legal safeguards against caste discrimination, which is pending final approval. 


\section{Persistence of Caste Discrimination and Inequalities}

Over a period of time, there has been substantial erosion in the institution of Caste. The situation of the scheduled caste has improved considerably. However, although the caste system has weakened in several spheres, it continues to retain some of its worst features even today. Reference to selected indicators of human development like per capita income, poverty, malnutrition, education, and assets ownership highlight the persisting inter caste inequalities and practice of caste discrimination.

In 2012, the average per capita income (in terms of monthly per capita consumption expenditure at current prices) was Rs 1645 at the all India level. However, it was Rs 2413 for high caste, Rs 1531 for other backward caste or OBC (a lower but not 'exuntouchable caste), and Rs 1294 for scheduled castes. The per capita income declines as we move from high caste to other backward castes and to the scheduled caste, indicating the persistence of graded inequality in income.

Similar inequality is observed for incidence of poverty, which increases in descending order of caste hierarchy. As against the poverty ratio of 22 per cent at all India level in 2012, only nine per cent among the high caste are poor, as compared to 20 per cent poor among $\mathrm{OBC}$ and 30 per cent for SC. Poverty affects nutrition and health status of the people at the bottom of the caste pyramid. In 2015/16 about 36 per cent of children under the age of five were underweight. The ratio was high with 39 percent for SC, 36 per cent for OBCs and 29 per cent for high caste. Similar graded inequality persists in educational attainment too. In 2014, about 78 per cent of students entered secondary /higher secondary level at the all India level. The enrolment rate was 97 per cent for high caste, followed by 80 per cent for $\mathrm{OBC}$ and 73 per cent for $\mathrm{SC}$. The enrolment rate for higher education was 43 per cent for high caste, 29 per cent for backward caste and 20 per cent for SC.

Thus, in case of all indicators of human development, namely per capita consumption expenditure, percentage of poor people, malnutrition, and educational attainment the graded inequality still persists. The low human development of the SC is primarily due to their low ownership of income earning assets, low education and employment, and also due to poor access to markets for employment and other things due to discrimination.

The ownership of wealth is heavily concentrated in the hands of high castes. In 2013, almost 45 per cent of the country's wealth was owned by high caste - almost twice their population share of 21 per cent. The OBCs owned about 31 per cent which is fairly close to their population share of 36 per cent. The SC on the other hand owned only seven per cent of the country's wealth share, much less than their population share of 17 per cent. The average value of wealth at all India level is Rs 1.5million. It is Rs 2.9 million for higher caste, followed by Rs 1.3 million for OBC, and just Rs six hundred thousand for SC. The scheduled caste average value of wealth is almost six times less than that of high caste and half of OBC.

Due to lack of access to income earning assets in 2011, about 44 per cent of scheduled caste workers in rural area depended on casual wage labour, compared to 26 per cent for $\mathrm{OBC}$ and 11 per cent of high caste dependent on casual labour. 
In this discrimination plays its part. In 2011/12, of the total gap in per capita monthly consumption expenditure between the scheduled castes and high caste, about 60 per cent was due to differences in ownership of capital assets (land and enterprises), employment and education, but the rest 40 per cent was due to caste discrimination. The gap was mainly on account of discrimination in wages, employment and occupation. The exercise for 2011/12 indicated that in the wage gap between the SC and high caste about 28.5 per cent was due to discrimination. In case of employment, about 70 per cent was due to employment discrimination. The job discrimination is high in whitecollar jobs, particularly in high paid administrative and professional jobs in the private sector.

Finding of a primary survey done in 2013 in villages of India, shows that the SC wage labour faces restrictions on hiring and wages, both in regular salaried and casual labour in selected works. The SC business persons engaged in grocery, restaurant/ eatery and transport service face discrimination in which their goods on sale and transport services are less used by the high caste affecting their income and profitability. Farmers face discrimination in purchase of inputs. While the access to inputs and employment is fairly open to scheduled caste, they also experience discrimination in many spheres, if not all. This affects the income of the scheduled caste wage workers, farmers, and business persons, resulting in high incidence of poverty among them. While this is the situation in case of economic opportunities, the civil rights sphere is not free from discrimination either despite legal safeguards. The Protection of Civil Right 1955 and Prevention of Atrocities Act 1989 allow the scheduled caste to register a legal complaint for denial of civil rights. However, during the period between 2001 to 2016, a total of 2,57,961 cases of atrocities against the SC were registered, which comes to a yearly average of 16,123 incidences of violation per year.

This very brief account of the status of the scheduled vis-à-vis the higher caste, shows that although there has been some improvement in the condition of SC, yet the caste system has remained a relatively stubborn institution. Although it has weakened in several spheres, it continues to retain some of its worst features.

Caste also shows its presence in other South Asian countries, particularly in Nepal, Bangladesh, Sri Lanka, and Pakistan. It is also seen as carry forward effects in the Indian diaspora in the United Kingdom, the United States, East Asia, Africa, and the Caribbean among descendants of Indian migrant populations

Caste relations persist in modified forms with negative consequences particularly for the lower castes that have not been able to shed the stigma in spite of conversions to other religions or integration in foreign societies and cultures. Today, caste system is a global issue.

\section{Part 3. About Vol. I., No. I: The Editors}

The first issue of this journal includes papers by scholars from many academic and professional disciplines who have worked on the issue of exclusion and discrimination. It comprises two sets of papers:

The first set comprises contributions by eminent scholars across the globe. These articles cover two types of issues; one related to access to basic needs such as food, 
health and housing, and the second related to caste-based atrocities and violence. The article by Nakkeeran et al. is an ethnographic enquiry into the pre-school Supplementary Nutrition Programme in India and attempts to understand the institutional barriers and sociological processes that led to the exclusion of families and children in accessing these essential services. The paper by Sanghmitra Acharya endeavours to understand the determinants of disparity among population groups across countries which influence access to health care with special reference to India. The paper by Vinod Kumar Mishra explores the nature, form, and pattern of discrimination faced by the scheduled castes or ex-untouchables, Muslims, and people from the Northeastern states while seeking rental accommodation in urban India. The exclusionary practices of landlords and brokers expose the dark underbelly of the urban rental housing market and its discouraging impact on the groups which are at the receiving end.

The article by Kalinga Tudor Silva examines how the rival Sinhala and Tamil nationalisms in Sri Lanka have contributed to 'caste blindness', a deliberate neglect of caste discrimination in public policies, while responding to the problem of longterm internally displaced people (IDP) in Jaffna Peninsula more than a decade after the end of war between the Government and separatists of the Liberation Tigers of Tamil Eelam. The paper by G. C. Pal is based on empirical research on 'mapping caste-based violence' in the contemporary Indian society. The paper sheds light on the diverse consequences of real or perceived violence, emanating from 'caste'. His analysis reveals that the consequences of caste violence are manifested in social, economic, psychological, and moral terms. The paper by Rajesh Sampath, attempts a critical commentary of Ambedkar's posthumously published, incomplete manuscript 'Philosophy of Hinduism'. Sampath attempts to draw out the profound implications of one of Ambedkar's last studies prior to his death, and argues for the centrality of both philosophy, and the philosophy of religion in Ambedkar studies in general.

The second set has articles written by emerging young researchers who have won the prestigious Bluestone Rising Scholars award 2019. There are six papers in this section (including two winners and four honorary mentions). Maya Pramod, winner of the Bluestone award, focuses on the rereading of the social history in Kerala of 'caste colonies', with focus especially on Dalit women. As a member of the oppressed community herself, she finds how the caste colonies serve as the index of their inferior social status, and far from empowering the Dalits, have led to their ghettoisation. The second article by Vivek V. Narayan, winner also of the Bluestone award, analyzes the genealogies of the human in colonial-era Travancore by focusing on three scenes exemplifying performative egalitarianisms: soulful enlightenment, repurposed Advaita, and radical Siddha Saiva. Both papers are based on Kerala but in different time and context.

The article by Mark E. Balmforth focuses on the underexplored aspect of the interrelationship between caste and slavery in South Asia, and underlines the value of considering South Asian slave narratives as source material into historiography and archivally obscured aspects of dominant caste identity. The paper by Sanober Umar addresses the interrelated connections between the production of Muslims as 'foreign' and the simultaneous relegation of Muslim 'indigenous' histories of conversion (from Dalit and lower caste backgrounds) to the periphery under ahistoric, demeaning, and monolith stereotypes of the 'backward Musalmaan.' The article by Subro Saha, explores the contingencies and paradoxes shaping the idealism/materialism separation in absolutist terms and analyzes the problems of such separatist tendencies in dealing 
with the question of caste. The article by Sunaina Arya seeks to initiate a theoretical rethinking of feminist as well as Dalit scholarship, with employment of analytical, hermeneutical, and critical methods by exposing flaws about 'dalit patriarchy' including a detailed discussion on the empirical, theoretical, and logical shortcomings.

The Forum of the issue has been contributed by eminent economist Jean Drèze who argues that the recent rise of Hindu nationalism in India can be seen as a revolt of the upper castes against the egalitarian demands of democracy. The first issue also incorporated three book reviews on recently published research on caste and social exclusion. And finally, we are honoured to have blessings and best wishes from His Holiness the Dalai Lama who in praising the launch of our journal says that caste "is a vestige of feudalism" and that the journal "can promote a sense of the oneness of the seven billion human beings." 